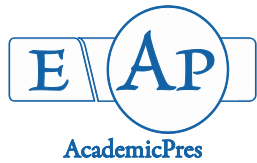

\title{
Improvement of Soil Properties, Growth of Cucumber and Protection against Fusarium Wilt by Piriformospora indica and Two Industrial Organic Wastes
}

\author{
Moustafa H.A. MOHARAM ${ }^{1,3 *}$, Mazhar D.A. MOHAMED ${ }^{2}$, \\ Osama E. NEGIM ${ }^{3}$ \\ ${ }^{1}$ Sohag University, Faculty of Agriculture, Plant Pathology Department, New Campus at El-Kawamel, Sohag P.O. 82755, \\ Egypt; moustafa.moharam@agr.sohag.edu.eg \\ ${ }^{2}$ Sohag University, Faculty of Agriculture, Microbiology Department, New Campus at El-Kawamel, Sohag P.O. 82755, \\ Egypt;mazhareisawi@yahoo.com \\ ${ }^{3}$ Sohag University, Faculty of Agriculture, Soil and Water Sciences Department, New Campus at El-Kawamel, Sohag P.O. 82755, \\ Egypt; onegim@yahoo.com (*correspondingauthor); moustafa.moharam@agr.sohag.edu.eg
}

\begin{abstract}
The current work was focused on characterizing bagasse ash (BA) and press mud (PM) as soil amendments and to study their effect in combination with the endophytic fungus Piriformospora indica on Fusarium wilt (FW) of cucumber caused by Fusarium oxysporum $\mathrm{f}$. sp. cucumerinum (Fo). Whereas BA and PM improved almost all physico-chemical properties of the soil evaluated, seed treatment with $P$. indica had no such effect. In shake culture in potato dextrose broth (PDB) medium amended with aqueous extracts of BA and PM, alone or in combination, production mycelial mass of Fo was significantly decreased by PM extract, while production mycelial mass of $P$. indica was highly improved. The colonization rate of cucumber roots by $P$. indica as determined by microscopy was highly increased by increasing amounts of BA, PM and BA+PM added to the soil. Seed treatment of cucumber with $P$. indica before plant cultivation in non-amended soil significantly decreased the disease severity of FW and improved plant growth. When seed treated with $P$. indica was sown into soil amended with BA, PM or the combination of both, the disease severity was even more reduced than after seed treatment with $P$. indica alone. In this respect, amendment with PM was more effective than with BA, and the combinations were more effective than the single treatments. Hence, there is a scope to integrate PM and BA as soil amendments in combination with $P$. indica for eco-friendly FW management, improving soil properties and growth of cucumber plants.
\end{abstract}

Keywords: cucumber, Fusarium wilt, Piriformospora indica, organic waste, protection Abbreviations: autoclaved soil (AS), bagasse ash (BA), barley sand medium (BSM), colony forming unit (cfu), deoxyribo nucleic acid (DNA), diethylenetriamine penta acetic acid (DEPTA), Disease severity (DS), distilled water (DW), sterile distilled water (SDW), dry weight (DrW). electrical conductivity (ECe), fresh weight (FrW), Fusarium oxysporum (Fo), Fusarium wilt (FW), non-autoclaved soil (NAS), Nutrient agar (NA), polymerase chain reaction (PCR), potato dextrose agar (PDA), press mud (PM), organic matter (OM). Piriformospora indica (P. indica).

\section{Introduction}

Because of the fact that soils recently reclaimed in the arid and semi-arid areas of Upper Egypt are very poor in organic matter, total $\mathrm{N}$, available $\mathrm{P}, \mathrm{K}$ and other essential macronutrients and micronutrients such as $\mathrm{Fe}, \mathrm{Cu}, \mathrm{Mn}$ and $\mathrm{Zn}$, it is highly desirable to improve the physical and chemical soil properties for the highest possible productivity of crops. For improving soil fertility in these areas, most farmers commonly tend to use unsafe muddy soils and organic materials that are often contaminated with diseases and chemicals causing harmful effects on plant, animal, and human. Therefore, alternative, safe ways to improve soil properties, crop productivity, and disease resistance are urgently needed. In this context, seed treatment with 
526

microorganisms along with the use of available safe organic soil amendments such as compost, vegetable residues, animal manures and organic wastes may be an alternative strategy.

For this purpose, various organic wastes of plant materials originating from controlled industrial sources have been reported as soil organic amendments for altering the physical, chemical and biotic conditions of the soil, improving plant growth and production (Razzaq, 2001; Solaimalai et al., 2001; Pandya et al., 2009; Sarwar et al., 2010; Khan, 2011; Ghulam et al., 2012; Patil et al., 2013; Yadav, 2014; Dotaniya et al., 2016; Nigem et al., 2016) and reducing the inoculum potential of pathogens (Pandya $e t$ al., 2009; Yadav, 2014; Dotaniya et al., 2016; Gilardi et al., 2016). Of such organic wastes available in Egypt, bagasse ash (BA) and press mud (PM) are industrial wastes associated with sugar production from sugarcane. The annual amount of these materials in sugar factories have been estimated at about 36 and 316 thousand tons of BA and PM, respectively, that have to be disposed of in an environmentally safe way (Nakhla and El Haggar, 2014). Although, sugarcane $\mathrm{BA}$ and PM are considered pollutants, they contain various nutrients that are vital for improving soil fertility, plant growth and production (Solaimalai et al., 2001; Rangaraj et al., 2007; Khan, 2011; Dotaniya et al., 2016; Moharam et al., 2016; Nigem et al., 2016). In general, BA has $47-52 \%$ hemicellulose, $25-28 \%$ cellulose, and $20-$ $21 \%$ lignin sugars, whereas PM contains $50-70 \%$ moisture, 20-30\% fiber, $7-15 \%$ crude wax, $5-12 \%$ sugars, $5-10 \%$ crude protein and 2-2.5\% nitrogen, and significant amounts of $\mathrm{Fe}$, Mn, Ca, Mg, Si, K, and P (Solaimalai et al., 2001; Gupta et al., 2011; Khan, 2011; Dotaniya et al., 2016). Considering the richness of nutrients of sugarcane PM and the mobilization in soil of insoluble $\mathrm{P}$ by organic acids produced from BA (Dotaniya, 2014; Dotaniya and Datta 2014; Dotaniya et al., 2016), both have the potential of becoming useful products for use in agriculture (Solaimalai et al., 2001). Based on several studies carried out in pots or under field conditions, application of BA or PM for improving soil physical, chemical and biological properties, and increasing organic matter and nutrient content has been recommended (Bokhtiar et al., 2000; Rangaraj et al., 2007; Jamil et al., 2008; Singh et al., 2008; Sarwar et al., 2010; Khan, 2011; Dotaniya et al., 2016).

The cucumber plant (Cucumis sativus L.) is one of the main economic vital vegetable crops grown in fields and under protected conditions. In Egypt and worldwide, the major disease causing severe losses in cucumber production is FW caused by the forma specialis (f.sp.) cucumerinum of the soil-inhabiting fungus Fusarium oxysporum Schlecht. Fr. (Jun-Li et al., 2010; Moharam and Negim, 2012). Several practices such as use of the resistant or tolerant cultivars, crop rotation, and fumigation to decrease the damage of FW have been suggested before ( $\mathrm{Yu}, 2001)$. Also, fungicide application is common, but may not be effective especially when the wilt appears late in the season (Srivastava $e t$ al., 2010).

Seed treatment with systemic fungicides before sowing controls the disease effectively, however, there are strong objections against their use due to potential toxic or other harmful effects in the environment. Hence, use of effective microorganisms along with organic wastes for FW management may be an alternative eco-friendly option.

Previous studies have shown the potential of certain bacteria and fungi to control FW, increase uptake of minerals and promote plant growth (Kennedy and Smith, 1995; Doran et al., 1996; Shivanna et al., 1996; Moharam and Negim, 2012). One of the candidate fungi recently tested for these purposes is $P$. indica, a plant-root-colonizing fungus belonging to the Basidiomycotina. It is a plant growth promoter which colonizes the root cortex and hairs of various plants and promotes nutrient and water uptake especially under extreme environmental stresses (Waller $e t$ al., 2005; Oelmüller et al., 2009; Zuccaro et al., 2009; Varma et al., 2012a; Varma et al., 2013; Bagheri et al., 2014; Moharam et al., 2017). It was also shown to confer systemic resistance and tolerance to pathogens in various plants (Varma et al., 2012b; Johnson et al., 2014; Moharam et al., 2017).

A number of publications have recently documented the potential of $P$. indica to control root diseases caused by Fusarium spp., e.g. in barley against $F$. culmorum and $F$. graminerarum (Waller et al., 2005; Deshmukh and Kogel, 2007; Harrach et al., 2013), in wheat against F. oxysporum (Moharam et al., 2017), in maize against $F$. verticillioides (Kumar et al., 2009), in tomato against $F$. oxysporum (Fakhro et al., 2010; Sarma et al., 2011) and in lentil against F. oxysporum f.sp. lentis (Dolatabadi et al., 2012). Despite the general potential of organic amendments applied alone or along with different microorganisms to control wilt diseases (Chakrabarti and Sen, 1991; Padmodaya and Reddy, 1999; Padmodaya, 2003; Bonanomi et al., 2007; Njoroge et al., 2008; BorregoBenjumea et al., 2014; Gilardi et al., 2016), only limited information is available on the use of sugarcane PM as soil amendment in combination with microorganisms like Trichoderma harzianum or Pseudomonas fluorescens against tomato wilt disease caused by $F$. oxysporum f. sp. lycopersici (Yadav, 2014). Also, populations in soil of bacteria and fungi increased (Ownen, 1954; OchaoGeorge et al., 2010) while nematodes (Anonymous, 1971; Alexander, 1972) and pathogenic fungi such as Fusarium and Pythium were suppressed (Anonymous, 1968). In vitro, aqueous extracts of PM caused $20.78 \%$ inhibition of $F$. solani growth (Pandya et al., 2009). Also, preparations from cashew (Anacardium occidentale L.) peduncle bagasse ash showed antifungal activity against $F$. oxysporum, $F$. moniliforme and F. lateritium (Santos et al., 2011). Therefore, the current study was carried out to evaluate the potential of $P$. indica and the two industrial organic wastes BA and PM applied to the soil alone or in combination for improving soil properties, growth and FW control of cucumber. Another objective of this investigation was to study the effects of BA and PM on growth of both Fo and $P$. indica in vitro, and on root colonization by $P$. indica in pot experiments. Further, the potential of $P$. indica to colonize the roots of cucumber plants grown in pots was studied by microscopy and PCR diagnosis. 


\section{Materials and Methods}

\section{Soil used and itsproperties}

The soil used here was collected from the Experimental Farm, Faculty of Agriculture, Sohag University at the geographical site of El-Kawamel, Sohag Governorate of Upper Egypt. The soil was immediately sieved through a screen (4-mm mesh) for use in the experiments, and through a 2-mm mesh screen for use in analyses of physical and chemical properties before planting (Khan, 2011). A soil aliquot $(50 \mathrm{~g})$ was used for particle size distribution analysis by sieving and pipette methods (Richards 1954). Dry bulk density and total porosity were determined by the core method according to the methodology described by (Blake and Hartge, 1996). Soil $\mathrm{pH}$ was measured in 1:1 soil: water suspension by $\mathrm{pH}$ meter (Orion model 410A) according to Jackson (1973). Electrical conductivity was determined in soil past extract (ECe) using electrical conductivity meter (Orion model 150) according to Jackson (1973). Organic matter (OM) content was estimated by a modified Walkley-Black method as elaborated by Jackson (1967). Calcium carbonate content was also determined volumetrically using the calibrated Collin's Calcimeter method as described by Jackson (1973). Soluble cations and anions were analysis in the saturated soil paste extracted according to Jackson (1973). Total N was determined by Kjeldahl procedure (Jackson, 1973). K was determined by ammonium acetate method (Black, 1965). P was determined by formation of a phospho molybdate complex (Lennox, 1979). Available metal content in the soil was determined by ICP mass Spectrometer (Icap6000 Series- Thermo Fisher Scientific Company) after using DTPA extractable micronutrients from the soil samples by 0.05 M DTPA at $\mathrm{pH} 7.3$ according to Lindsay and Norvel (1978). The physico-chemical characteristics of this soil determined are listed in Table 1.
Organic wastes: properties, extraction and amendment application

The organic wastes $\mathrm{BA}$ and $\mathrm{PM}$ used in the present investigation were obtained from the industry sugar Mills, Qena Governorate, Egypt. The materials were ground to pass through $2 \mathrm{~mm}$ sieve and analysed to determine different chemical characteristics. Table 2 presented the chemical characteristics of PM and BA. To prepare the stock of $10 \%$ aqueous extract of BA and PM, $10 \mathrm{~g}$ of each organic material were suspended in $100 \mathrm{ml}$ distilled water (DW) in conical flasks, and placed on a rotary shaker at room temperature. After 25 days, the contents of the flasks were carefully filtered through double layers of muslin cloth, autoclaved for $20 \mathrm{~min}$ (Pandya et al., 2009) and then kept in a refrigerator for later use. Before starting the trials, the organic materials of $\mathrm{BA}, \mathrm{PM}$ and $\mathrm{BA}+\mathrm{PM}$ were carefully mixed into the soil $(2.5$ and $5 \%, w: w)$. The mixture was then irrigated with water (to reach $75 \%$ of the soil moisture capacity) and afterwards immediately covered with transparent polyethylene sheets. After 14 days, the cover was removed and the mixture was left to dry with daily mixing for 2 weeks before use.

\section{Plant and fungal materials and inoculation methods}

Cucumber seeds of cultivar Denmark Beta-Alpha, which is susceptible to FW (Moharam and Negim, 2012) were used. Seeds were surface disinfected with $1.5 \%$ sodium hypochlorite for $10 \mathrm{~min}$, rinsed 3 times with sterile distilled water (SDW), and then immersed again in SDW for $3 \mathrm{~h}$ followed by placement in hot SDW at $60^{\circ} \mathrm{C}$ for $5 \mathrm{~min}$ to kill any endophytes inside the seeds (Huang and Backhouse, 2005) and then left for air drying under aseptic conditions. Seeds were then tested for absence of the internal endophytes before treating and planting by placing subsamples of treated seeds in Petri plates on potato dextrose agar (PDA) medium.

Table 1.The physico-chemical characteristics of the studied soil

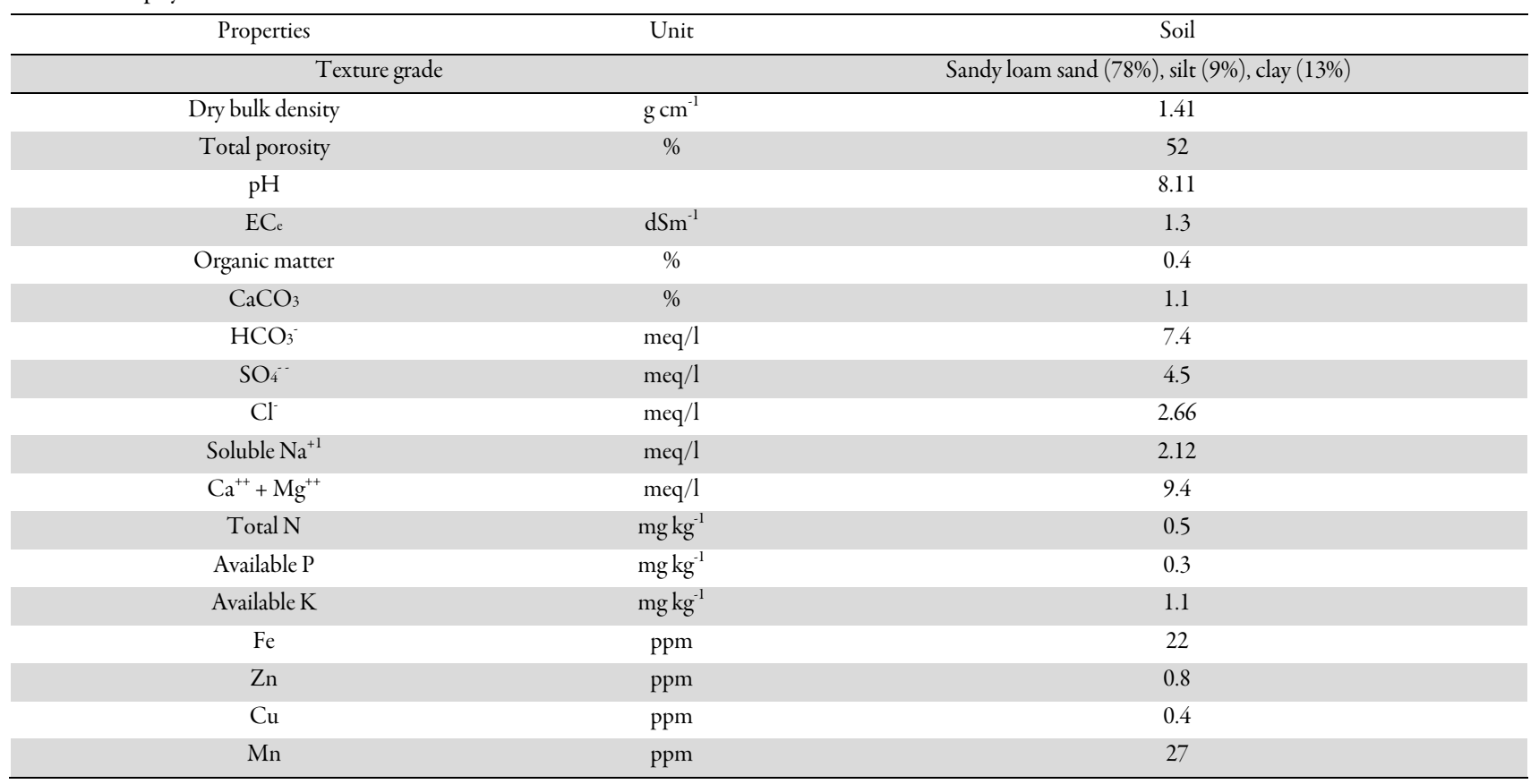


Table 2. Chemical analysis of BA and PM used in this study

\begin{tabular}{|c|c|c|c|}
\hline Analysis & Unit & $\mathrm{BA}$ & PM \\
\hline \multicolumn{2}{|c|}{ Form } & Powder & Soft, spongy \\
\hline $\mathrm{pH}$ & & 8.6 & 7.22 \\
\hline $\mathrm{EC}$ & $\mathrm{d} S \mathrm{~m}^{-1}$ & 2.38 & 3.44 \\
\hline Total N & $\%$ & 0.4 & 0.9 \\
\hline Total P & $\%$ & 0.3 & 0.8 \\
\hline Total K & $\%$ & 0.5 & 0.3 \\
\hline $\mathrm{Ca}$ & $\%$ & 0.4 & 0.9 \\
\hline $\mathrm{Mg}$ & $\%$ & 0.5 & 0.6 \\
\hline $\mathrm{OM}$ & $\%$ & 3.40 & 6.64 \\
\hline $\mathrm{Fe}$ & $\mathrm{ppm}$ & 442 & 536 \\
\hline $\mathrm{Zn}$ & $\mathrm{ppm}$ & 35 & 102 \\
\hline $\mathrm{Cu}$ & ppm & 66 & 44 \\
\hline $\mathrm{Mn}$ & $\mathrm{ppm}$ & 78 & 203 \\
\hline
\end{tabular}

Two fungal isolates, $F$. oxysporum $\mathrm{f}$. sp. cucumerinum (Fo) and $P$. indica used in this study were obtained from the culture collections of the Department of Plant Pathology, Sohag University, Egypt. To prepare the inoculum of Fo, the fungus was grown in autoclaved barley sand medium (BSM) at $28 \pm 5^{\circ} \mathrm{C}$ for two weeks. Afterward, the inoculum was added to the BA and PM -amended soil (3\%,w:w) as described above. The mixture was then slightly irrigated every other day for a week before planting. The stock culture of $P$. indica was cultured at $28 \pm 5^{\circ} \mathrm{C}$ and maintained at $4{ }^{\circ} \mathrm{C}$ on slope containing Kaefer agar medium (Prasad $e t$ al., 2005). To prepare inoculum of $P$. indica, the fungus was re-cultured on PDA plates at $28 \pm 5^{\circ} \mathrm{C}$ and then propagated on a rotary shaker at $28 \pm 5^{\circ} \mathrm{C}$ in PDA broth medium for two weeks. For inoculation with $P$. indica, cucumber seeds were immersed in an aqueous solution of $0.05 \%$ Tween 20 containing $5 \times 10^{5}$ chlamydospores $\mathrm{ml}^{-1}$ for one hour before sowing (Varma et al., 1998).

\section{In vitro test for antagonistic activity}

Antagonism between $P$. indica and Fo was tested by the dual culture technique described by Ghahfarokhi and Goltapeh (2010). A 7-mm disc of Fo mycelium taken from the peripheral region of a 7 day-old culture was placed on one side of a PDA plate $(9 \mathrm{~cm}$ in diameter). A $7 \mathrm{~mm}$ disc of $P$. indica obtained from the margin of a 14 day-old culture was placed on the other side of the plate. PDA plates inoculated with Fo or $P$. indica alone served as controls. All plates were then incubated at $28 \pm 5{ }^{\circ} \mathrm{C}$ for 7 days and afterwards the radial growth $(\mathrm{cm})$ of Fo and $P$. indica was measured. The entire experiment included 4 plates of each treatment and was repeated twice. Percent growth inhibition was calculated by the formula: Inhibition of mycelial growth $(\%)=\mathrm{C}-\mathrm{T} / \mathrm{C} \times 100$. Where $\mathrm{C}=$ growth in control and $\mathrm{T}=$ growth in treatment.

In vitro effects of aqueous extracts of organic wastes on growth of Fo and $P$. indica

The effect of aqueous extract of BA and PM on biomass production of Fo and $P$. indica was determined. The stock of $10 \%$ aqueous extract of each organic material (see above) was added to conical flasks containing sterilized PDA broth medium to get final concentrations of $0.5,1,1.5,2,2.5$ and $3 \%$. The controls were flasks containing PDA broth medium amended with SDW. The flasks were then inoculated with 7-mm agar discs from $\mathrm{s} 7$ day-old cultures of each tested fungus before incubation on a rotary shaker at $28 \pm 5^{\circ} \mathrm{C}$. Four flasks were employed for each concentration. After 7 days, the biomass production of Fo and $P$. indica as dry weight $(\mathrm{g})$ was determined and means were calculated.

\section{Greenhouse experiments}

Two greenhouse trials, each laid out in a randomized block design, with six replications of each treatment were conducted in the 2016 summer growing season. Autoclaved soil (AS) and non-autoclaved soil (NAS) was amended with $0,2.5$ or $5 \%$ of each organic waste alone or in combination, inoculated with Fo (3\%, w/w; preparation see above) by mixing and then slightly watered daily for a week. Soils amended with the same amount of BSM and organic wastes were used as controls. Afterward, formalin-sterilized pots $(30 \mathrm{~cm})$ were filled with the treated AS and NAS. Seeds of cucumber were sterilized and inoculated with $P$. indica as mentioned before, and then sown at the rate of 5 seeds per each pot. Pots were then irrigated when necessary. Percent of wilted plants was determined after 6 weeks, and the plants were then individually rated for severity of FW using a scale of $0-3$, where $0=$ healthy plants, no visible symptoms; $1=$ weakly infected plant showing vascular discoloration, but no leaf yellowing; $2=$ moderately infected plants showing leaf yellowing and wilt; $3=$ severely infected plants showing plant death (Ha et al., 2008). Disease severity (DS \%) for each replication of each treatment was calculated by the formula: $(\Sigma \mathrm{Si} \times \mathrm{Ni}) \times 100 /(3 \times \mathrm{Nt})$, where $\mathrm{Si}$ is the severity ratings $0-3, \mathrm{Ni}$ is the number of plants in each rating, and $\mathrm{Nt}$ is the total number of rated plants (Moharam and Negim, 2012). At 14 and 28 days after planting the roots from 10 plants per treatment were collected for light microscopy and PCR diagnosis of root colonization by $P$. indica (see below).

Six whole plants (including the root rhizosphere) were randomly taken from each treatment after 6 weeks of growth and the fresh and dry weights $(\mathrm{g})$ of vegetative growth were determined. Also, total cfu-counts of Fo, $P$. indica, bacteria and other fungi in the rhizosphere per plant 
were determined on PDA and Nutrient agar (NA) medium for fungi and bacteria, respectively using serial dilution method described by Vieira and Nahas (2005). Moreover, soil from each replication of each treatment was collected, homogeneously mixed and then used in analyses of physicochemical characteristics.

\section{Colonization of cucumber roots by $P$. indica}

\section{A-Staining and microscopy}

Root samples of 14 and 28 day-old plants collected from pots were washed thoroughly with tap water. Hand sections were prepared from roots using a razor blade and stained with $0.1 \%$ trypan blue according to the method described by Kollmorgen and Ballinger (1987). Sections were then mounted in lactophenol and examined by a light microscope (Leica ATC 2000, India) equipped with a digital camera (Optika 9.2 MP, Type 4083.B9, Italy) using the $40 \times$ lens.

\section{$B$ - $P C R$ diagnosis}

Genomic DNA was extracted from fungal mycelium of $P$. indica and from fresh root samples of 14 and 28 day-old plants using the DNeasy Plant mini Kit (Qiagen, Germany) according to the manufacturer's instructions. Using PCR diagnosis an approx. 751-bp fragment was amplified from extracted $P$. indica DNA from both fungal pure culture (positive control) and from inoculated plants using the specific primer pair 5'-TTCTGGGAAGTCGTCTCTG$3^{\prime}$ and $5^{\prime}$-AGCCAACCATGAAGAAGTG-3' targeting the annotated sequence (AJ459235) of the $\beta$-tubulin (Serfling et al., 2007). PCR reactions were performed in a total volume of $20 \mu \mathrm{l}$ including $0.25 \mu \mathrm{M}$ of each primer, 2.5 $\mathrm{mM} \mathrm{MgCl} 2,0.5 \mathrm{mM}$ dNTPs, $1 \mathrm{x}$ reaction buffer, Taq DNA polymerase at $0.4 \mathrm{U} / \mu \mathrm{l}$ (all reagents from Qiagen, Germany) and $100 \mathrm{ng}$ of template DNA. Amplification reactions were performed according to a PCR protocol consisting of $95^{\circ} \mathrm{C}$ for $180 \mathrm{~s}$; followed by 35 cycles of $95^{\circ} \mathrm{C}$ for $30 \mathrm{~s}, 51.5^{\circ} \mathrm{C}$ for $30 \mathrm{~s}$, and $72^{\circ} \mathrm{C}$ for $90 \mathrm{~s}$; and a final extension at $72^{\circ} \mathrm{C}$ for 10 min. PCR products were analyzed and examined on $1 \%$ agarose gels run at $100 \mathrm{~V}$ in $1 \mathrm{x}$ TAE buffer and gels were then stained with ethidium bromide for visualization. Negative controls used either SDW or DNA extracted from roots of non-inoculated plants.

\section{Statistical analysis}

Data obtained were inputted into MSTAT-C program. Analysis of variance was performed and the least significant difference (L.S.D.) of means was calculated at $\mathrm{P}=0.05$ and 0.01 (Gomez and Gomez 1984).

\section{Results}

\section{Interaction of $P$. indica and Fo in vitro}

In a dual culture test performed to identify antagonistic activity of $P$. indica against and Fo on PDA medium after 7 days of incubation at $28 \pm 5{ }^{\circ} \mathrm{C}$, clear antagonism not detected (Fig. 1).

\section{Effect of aqueous extract of $B A$ and $P M$ on growth of $F o$ and P. indica}

In shake culture in $\mathrm{PDB}$ medium supplied with aqueous extracts of BA and PM alone or in combination (Table 3), production of Fo mycelial mass (dry weight) was significantly decreased by PM extract. Compared to the control, mycelial mass was reduced by $25.76 \%$ at the concentration of $2.5 \%$. Increasing the concentration to $3 \%$ had no additional effect. On the other hand, BA extract

Table 3. Effect of aqueous extracts of BA and PM on biomass production of Fo and P. indica in vitro

\begin{tabular}{|c|c|c|c|}
\hline \multirow{2}{*}{ Extract } & \multirow{2}{*}{$\begin{array}{c}\text { Concentration } \\
(\%)\end{array}$} & \multicolumn{2}{|c|}{ Biomass production $(\mathrm{mg})^{*}$} \\
\hline & & Fo & P. indica \\
\hline \multirow{7}{*}{ BA } & 0.0 & 295 & 177 \\
\hline & 0.5 & 301 & 187 \\
\hline & 1.0 & 308 & 198 \\
\hline & 1.5 & 315 & 211 \\
\hline & 2.0 & 323 & 223 \\
\hline & 2.5 & 329 & 235 \\
\hline & 3.0 & 331 & 237 \\
\hline \multirow{7}{*}{ PM } & 0.0 & 295 & 177 \\
\hline & 0.5 & 278 & 183 \\
\hline & 1.0 & 257 & 191 \\
\hline & 1.5 & 237 & 199 \\
\hline & 2.0 & 226 & 217 \\
\hline & 2.5 & 219 & 226 \\
\hline & 3.0 & 217 & 227 \\
\hline \multirow{7}{*}{$\mathrm{BA}+\mathrm{PM}$} & 0.0 & 295 & 177 \\
\hline & 0.5 & 284 & 191 \\
\hline & 1.0 & 272 & 201 \\
\hline & 1.5 & 267 & 215 \\
\hline & 2.0 & 259 & 227 \\
\hline & 2.5 & 251 & 239 \\
\hline & 3.0 & 249 & 241 \\
\hline
\end{tabular}



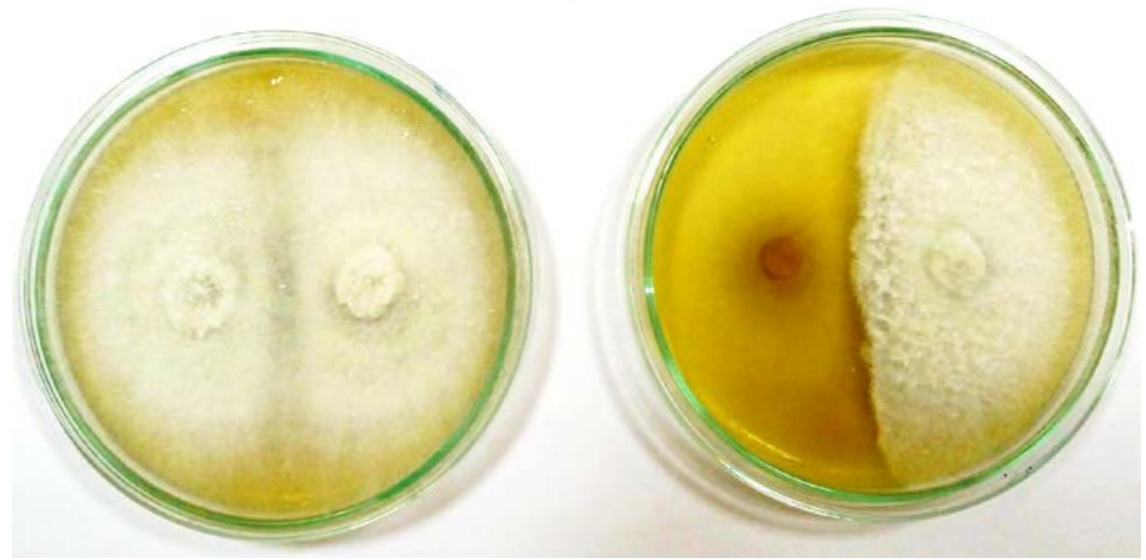

Fig. 1. Lack of the antagonistic effect between P. indica and Fo in vitro. Left PDA plate (control) inoculated with two discs of Fo; The right plate was included with one disc of Pi (left) and one of Fo (right)

promoted the growth of Fo. In the case of $P$. indica, production of mycelial mass was increased by increasing concentrations of BA extract, PM extract and the combination of both. The highest production of mycelial mass was recorded for PDB amended with both BA and PM extract.

\section{Colonization of cucumber roots by P. indica}

Microscopic examination of hand-cut sections of cucumber roots of 14 and 28 day-old plants grown from $P$. indica-inoculated seeds and stained with trypan blue revealed the presence of $P$. indica chlamydospores within the root cortex cells (Fig. 2). At the same growth stages, $P$. indica was detected by PCR in DNA extracted from roots of plants from the same treatments. PCR amplified a single product of approx. 751-bp in length both in DNA extracted from a pure culture of $P$. indica (Fig. 3, lane 2) and in DNA extracted from the plants (lanes 4 and 5). No amplification product was detected after PCR with DNA extracted from the roots of non-inoculated plants (fig. 3, lane 3) and in the negative control (SDW, lane 1).

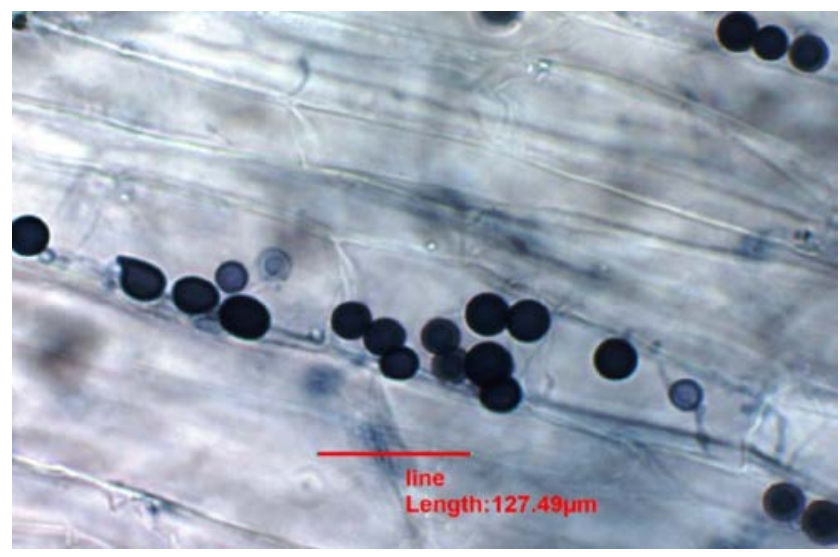

Fig. 2. A hand-cut section of cucumber roots stained with trypan blue showing the intracellular chlamydospores of $P$. indica within root cortex cells of 14 day-old plants. Likewise, in 28 day-old plants tested
Effect of organic wastes as soil amendments and seed treatment with P. indica on:

\section{A-Soilphysico-chemical and biological properties \\ A-1-Physico-chemical properties}

The comparison between the soil in Table 1 and soil of the column "No amendment" in Table 4 after analysis shows that seed treatment with $P$. indica had no effect on the physico-chemical soil properties. On the other hand, amendments with BA and PM were effectively improved almost all physico-chemical properties of the soil. The degree of improvement was generally higher at the concentration of $5.0 \%$ compared to $2.5 \%$. Values of dry bulk density of soil were decreased after application of BA, $\mathrm{PM}$ and BA+PM, compared with initial bulk density (1.4 $\mathrm{g} / \mathrm{cm} 3)$. It was noticed that the lowest bulk density value $\left(1.35 \mathrm{~g} / \mathrm{cm}^{3}\right)$ was recorded with high rates of PM additions which ultimately led to an increase of soil total porosity as compared with the controls (no amendment). Application of $\mathrm{PM}$ and $\mathrm{BA}+\mathrm{PM}$ also decreased the soil $\mathrm{pH}$ slightly,

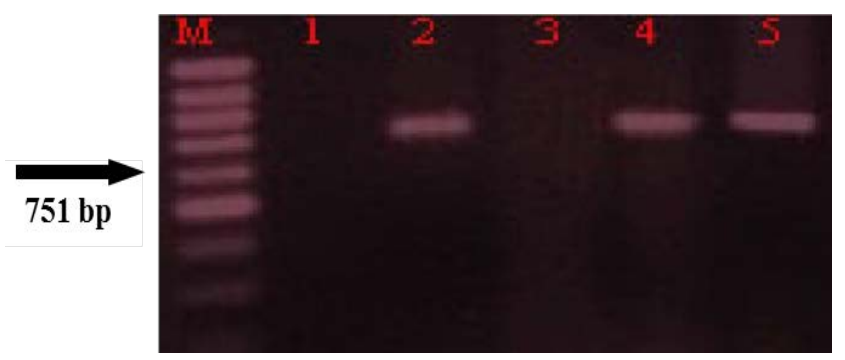

Fig. 3. PCR detection of $P$. indica in DNA of cucumber roots with the designed specific primer pair of an annotated sequence of the $\beta$-tubulin gene. ' $M$ ' denotes a $100 \mathrm{bp}$ ladder DNA size standard (AppliChem, Darmstadt, Germany). Lanes 1-5 show PCR results from different DNA templates, under otherwise identical conditions. Lane 1: sterile distillated water (negative control); Lane 2: DNA extracted from pure culture of $P$. indica (positive control); lane 3: DNA from root of noninoculated cucumber; lane 4 and 5: DNA from the root of inoculated plants harvested after 14 and 28 days, respectively 
Table 4. Effect of amendment with BA and PM and seed treatment with $P$. indica on physical and chemical properties of the soil. All treatments include a seed treatment with $P$. indica

\begin{tabular}{|c|c|c|c|c|c|c|c|c|}
\hline \multirow{3}{*}{ Properties } & \multirow{3}{*}{ Unit } & \multirow{3}{*}{$\begin{array}{c}\text { No } \\
\text { amendment }\end{array}$} & \multicolumn{6}{|c|}{ Amendment } \\
\hline & & & \multicolumn{2}{|c|}{$\mathrm{BA}$} & \multicolumn{2}{|c|}{ PM } & \multicolumn{2}{|c|}{$\mathrm{BA}+\mathrm{PM}$} \\
\hline & & & $2.5 \%$ & $5 \%$ & $2.5 \%$ & $5 \%$ & $2.5 \%$ & $5 \%$ \\
\hline Texture & - & Sandy loam & Sandy loam & Sandy loam & Sandy loam & Sandy loam & Sandy loam & Sandy loam \\
\hline Dry bulk density & $\mathrm{g} \mathrm{cm}^{-1}$ & 1.41 & 1.38 & 1.37 & 1.38 & 1.35 & 1.37 & 1.36 \\
\hline Total porosity & $\%$ & 52 & 52.4 & 52.7 & 52.2 & 52.4 & 52.3 & 52.6 \\
\hline $\mathrm{pH}$ & - & 8.1 & 8.2 & 8.4 & 7.8 & 7.6 & 8.0 & 7.8 \\
\hline $\mathrm{EC}_{\mathrm{e}}$ & $\mathrm{d} S \mathrm{~m}^{-1}$ & 1.3 & 1.6 & 2.2 & 1.8 & 2.4 & 1.9 & 2.5 \\
\hline Organic matter & $\%$ & 0.5 & 0.6 & 0.8 & 0.92 & 1.1 & 0.67 & 0.95 \\
\hline $\mathrm{HCO}_{3}^{-}$ & meq/l & 7.4 & 7.9 & 9.2 & 8.8 & 10.5 & 8.1 & 10.2 \\
\hline $\mathrm{SO}_{4}$ & $\mathrm{meq} / 1$ & 4.5 & 5.2 & 7.8 & 6.1 & 8.3 & 7.6 & 8.2 \\
\hline $\mathrm{Cl}^{-}$ & $\mathrm{meq} / 1$ & 2.66 & 2.8 & 3.5 & 3.2 & 4.4 & 2.9 & 5.1 \\
\hline Soluble $\mathrm{Na}^{+1}$ & meq/l & 2.12 & 3.3 & $5 . .4$ & 4.7 & 6.4 & 3.1 & 5.7 \\
\hline $\mathrm{Ca}^{++}+\mathrm{Mg}^{++}$ & meq/l & 9.4 & 11.2 & 12.6 & 13.4 & 16.5 & 13.1 & 18.2 \\
\hline Total N & $\mathrm{mg} \mathrm{kg}^{-1}$ & 0.5 & 0.6 & 0.7 & 0.9 & 1.2 & 0.8 & 1.0 \\
\hline Available P & $\mathrm{mg} \mathrm{kg}^{-1}$ & 0.3 & 0.6 & 0.8 & 1.1 & 1.8 & 0.7 & 1.5 \\
\hline Available K & $\mathrm{mg} \mathrm{kg}^{-1}$ & 1.1 & 1.6 & 1.8 & 1.8 & 2.3 & 1.5 & 2,4 \\
\hline $\mathrm{Fe}$ & ppm & 22 & 28.4 & 32.3 & 30.8 & 36.0 & 27.0 & 33 \\
\hline $\mathrm{Zn}$ & ppm & 0.8 & 1.2 & 1.8 & 2.6 & 3.9 & 1.8 & 2.7 \\
\hline $\mathrm{Cu}$ & $\mathrm{ppm}$ & 0.4 & 0.9 & 1.1 & 1.2 & 1.6 & 0.9 & 1.3 \\
\hline $\mathrm{Mn}$ & ppm & 27 & 28 & 31 & 32 & 37 & 29 & 39 \\
\hline
\end{tabular}

whereas the BA application slightly increased the $\mathrm{pH}$ compared with the control. The lowest value of soil $\mathrm{pH}$ was recorded in the treatment receiving the high addition rate of PM and the highest value was recorded in control. Moreover, soil electrical conductivity was increased by addition of PM, BA and BA+PM compared with control. The highest value was recorded in the treatment received the maximum application rate of BA. Organic matter content of the soil was sufficiently increased by PM and $\mathrm{BA}+\mathrm{PM}$ applications up to $5.0 \%$, and the vice versa was in case BA application. It was slightly increased $(0.8 \%)$ by $5.0 \%$. Soil macro and micronutrient such as NPK, Fe, Zn, $\mathrm{Cu}$ and $\mathrm{Mn}$ were increased after application of BA, PM and $\mathrm{BA}+\mathrm{PM}$. However, application of PM (2.5\%) was better than BA application (5\%) for increasing soil contents of macro and micronutrients. Application of BA+PM up to $5 \%$ resulted in the highest contents of soil macro and micronutrients (Table 4) when compared to the control.

\section{A-2-Biological properties}

In general, application of PM, BA and BA+PM to the soil increased bacterial and fungal populations in the rhizosphere of cucumber plants inoculated and noninoculated with $P$. indica as compared with non-amended soil (Table 5). Again, PM application was more effective than application of BA, application at $5 \%$ was more effective than at $2.5 \%$ and the combinations were more effective than the single treatments.

\section{A-3-Root colonization by P. indica}

The effects of soil amendment with BA and PM on root colonization of cucumber after seed inoculation with $P$. indica were evaluated by light microscopy and/or PCR diagnosis. The obtained results showed that the colonization rate of cucumber roots by $P$. indica as determined by microscopy (Table 6a and b) and/or PCR (data not shown) was highly increased by increasing

Table 5. Effect of organic wastes as soil amendments on bacterial and fungal population in rhizosphere of cucumber plants grown in non-autoclaved soil after inoculation of seeds with Pi under greenhouse conditions

\begin{tabular}{|c|c|c|c|c|c|}
\hline \multirow{3}{*}{$\begin{array}{l}\text { Organic } \\
\text { waste }\end{array}$} & \multirow{3}{*}{$\begin{array}{c}\text { Conc. } \\
(\%)\end{array}$} & \multicolumn{4}{|c|}{ Total count (cfu per g of soil rhizosphere) } \\
\hline & & \multicolumn{2}{|c|}{ Bacteria } & \multicolumn{2}{|c|}{ Fungi } \\
\hline & & $\begin{array}{c}\text { Inoculated } \\
\text { with } P \text {. indica }\end{array}$ & $\begin{array}{c}\text { Non-inoculated with } P \text {. } \\
\text { indica }\end{array}$ & $\begin{array}{c}\text { Inoculated } \\
\text { with } P \text {. indica }\end{array}$ & $\begin{array}{c}\text { Non-inoculated with } \\
\text { P. indica }\end{array}$ \\
\hline \multirow{3}{*}{ BA } & 0.0 & $9 \times 10^{6}$ & $11 \times 10^{6}$ & $29 \times 10^{4}$ & $34 \times 10^{4}$ \\
\hline & 2.5 & $13 \times 10^{6}$ & $17 \times 10^{6}$ & $33 \times 10^{4}$ & $37 \times 10^{4}$ \\
\hline & 5.0 & $19 \times 10^{6}$ & $23 \times 10^{6}$ & $37 \times 10^{4}$ & $41 \times 10^{4}$ \\
\hline \multirow{3}{*}{ PM } & 0.0 & $9 \times 10^{6}$ & $11 \times 10^{6}$ & $29 \times 10^{4}$ & $29 \times 10^{4}$ \\
\hline & 2.5 & $15 \times 10^{6}$ & $24 \times 10^{6}$ & $35 \times 10^{4}$ & $39 \times 10^{4}$ \\
\hline & 5.0 & $22 \times 10^{6}$ & $35 \times 10^{6}$ & $42 \times 10^{4}$ & $44 \times 10^{4}$ \\
\hline \multirow{3}{*}{$\mathrm{BA}+\mathrm{PM}$} & 0.0 & $9 \times 10^{6}$ & $11 \times 10^{6}$ & $29 \times 10^{4}$ & $29 \times 10^{4}$ \\
\hline & 2.5 & $17 \times 10^{6}$ & $26 \times 10^{6}$ & $37 \times 10^{4}$ & $42 \times 10^{4}$ \\
\hline & 5.0 & $25 \times 10^{6}$ & $39 \times 10^{6}$ & $45 \times 10^{4}$ & $47 \times 10^{4}$ \\
\hline
\end{tabular}

${ }^{*}$ Mean population of soil rhizosphere of 12 plants each in both experiments. 
532

Table 6a. Colonization by $P$. indica of cucumber roots of 28 day-old plants grown in autoclaved soil without or with amendments. The table shows the number of colonized plants determined by light microscopy $(\mathrm{n}=20)$

\begin{tabular}{|c|c|c|c|c|c|c|}
\hline \multirow{3}{*}{ No amendment } & \multicolumn{6}{|c|}{ Amendment } \\
\hline & \multicolumn{2}{|c|}{$\overline{B A}$} & \multicolumn{2}{|c|}{ PM } & \multicolumn{2}{|c|}{$\mathrm{BA}+\mathrm{PM}$} \\
\hline & $2.5 \%$ & $5 \%$ & $2.5 \%$ & $5 \%$ & $2.5 \%$ & $5 \%$ \\
\hline 10 (\% increase) & $11(10 \%)$ & $13(30 \%)$ & $13(30 \%)$ & $15(50 \%)$ & $14(40 \%)$ & $17(70 \%)$ \\
\hline
\end{tabular}

Table 6 b. Colonization by $P$. indica of cucumber roots of 28 day-old plants grown in non-autoclaved soil without or with amendments. The table shows the number of colonized plants determined by light microscopy $(n=20)$

\begin{tabular}{cccccccc}
\hline \multirow{2}{*}{ No amendment } & \multicolumn{7}{c}{ Amendment } \\
\cline { 2 - 8 } & \multicolumn{3}{c}{ BA } & \multicolumn{3}{c}{ PM } & \multicolumn{3}{c}{ BA+PM } \\
\cline { 2 - 8 } & $2.5 \%$ & $5 \%$ & $2.5 \%$ & $5 \%$ & $2.5 \%$ & $5 \%$ \\
\hline 8 (\% increase) & $8(0 \%)$ & $10(25 \%)$ & $10(37.5 \%)$ & $13(62.5 \%)$ & $12(50 \%)$ & $13(75 \%)$ \\
\hline
\end{tabular}

Table 7a. Effect of seed inoculation of cucumber with P. indica and soil amendment with organic wastes on disease severity of FW in the greenhouse in autoclaved soil

\begin{tabular}{|c|c|c|c|c|c|c|c|c|c|c|}
\hline \multirow{3}{*}{ Inoculation } & \multicolumn{10}{|c|}{ Amendment } \\
\hline & \multirow{2}{*}{ No amendment } & \multicolumn{3}{|c|}{$\mathrm{BA}$} & \multicolumn{3}{|c|}{ PM } & \multicolumn{3}{|c|}{$\mathrm{BA}+\mathrm{PM}$} \\
\hline & & $2.5 \%$ & $5 \%$ & Mean & $2.5 \%$ & $5 \%$ & Mean & $2.5 \%$ & $5 \%$ & Mean \\
\hline Fo & $39.7^{* * a}$ & $38.6^{a}$ & $37.4^{2}$ & $38.0^{2}$ & $36.8^{2}$ & $34.7^{a}$ & $35.8^{\mathrm{a}}$ & $37.1^{\mathrm{a}}$ & $33.7^{a}$ & $35.4^{2}$ \\
\hline $\mathrm{Fo}+P$. indica & $14.6^{b}$ & $2.5^{b}$ & $1.3^{b}$ & $1.9^{\mathrm{b}}$ & $1.2^{b}$ & $0.7^{b}$ & $0.9^{\mathrm{b}}$ & $0.4^{\mathrm{b}}$ & $0.1^{\mathrm{b}}$ & $0.2^{\mathrm{b}}$ \\
\hline Control $^{*}$ & $0.0^{\mathrm{c}}$ & $0.0^{\mathrm{c}}$ & $0.0^{\mathrm{c}}$ & $0.0^{\mathrm{c}}$ & $0.0^{\mathrm{c}}$ & $0.0^{\mathrm{c}}$ & $0.0^{\mathrm{c}}$ & $0.0^{\mathrm{c}}$ & $0.0^{\mathrm{c}}$ & $0.0^{\mathrm{c}}$ \\
\hline L.S.D. 0.05 & 0.15 & 0.09 & 0.04 & 0.08 & 0.07 & 0.04 & 0.04 & 0.04 & 0.04 & 0.04 \\
\hline
\end{tabular}

${ }^{*}$ No inoculation with Fo and $P$. indica.

** The values are means of disease severity $(\%)$ from total 60 plants represent each treatment in both experiments. Letters a, b, c and d of values are the rank of significant difference according to ANOVA (L.S.D. $\mathrm{p}=0.05)$.

Table 7 b. Effect of seed inoculation of cucumber with P. indica and soil amendment with organic wastes on disease severity of FW in the greenhouse in non-autoclaved soil

\begin{tabular}{|c|c|c|c|c|c|c|c|c|c|c|}
\hline \multirow{3}{*}{ Inoculation } & \multicolumn{10}{|c|}{ Amendment } \\
\hline & \multirow{2}{*}{ No amendment } & \multicolumn{3}{|c|}{$\mathrm{BA}$} & \multicolumn{3}{|c|}{ PM } & \multicolumn{3}{|c|}{$\mathrm{BA}+\mathrm{PM}$} \\
\hline & & $2.5 \%$ & $5 \%$ & Mean & $2.5 \%$ & $5 \%$ & Mean & $2.5 \%$ & $5 \%$ & Mean \\
\hline Fo & $36.7^{* * a}$ & $34.6^{a}$ & $32.4^{a}$ & $33.5^{a}$ & $32.4^{a}$ & $30.6^{a}$ & $31.5^{a}$ & $30.7^{\mathrm{a}}$ & $28.4^{\mathrm{a}}$ & $29.6^{a}$ \\
\hline $\mathrm{Fo}+$ P. indica & $11.2^{\mathrm{b}}$ & $2.1^{b}$ & $1.3^{\mathrm{b}}$ & $1.7^{\mathrm{b}}$ & $0.8^{\mathrm{b}}$ & $0.3^{\mathrm{b}}$ & $0.5^{b}$ & $1.1^{\mathrm{b}}$ & $0.4^{\mathrm{b}}$ & $0.7^{b}$ \\
\hline Control $^{*}$ & $0.0^{c}$ & $0.0^{c}$ & $0.0^{c}$ & $0.0^{c}$ & $0.0^{c}$ & $0.0^{c}$ & $0.0^{\mathrm{c}}$ & $0.0^{c}$ & $0.0^{c}$ & $0.0^{\mathrm{c}}$ \\
\hline L.S.D. 0.05 & 0.13 & 0.07 & 0.04 & 0.04 & 0.04 & 0.04 & 0.04 & 0.04 & 0.04 & 0.04 \\
\hline
\end{tabular}

${ }^{*}$ No inoculation with Fo and $P$. indica.

${ }^{* *}$ The values are means of disease severity $(\%)$ from total 60 plants represent each treatment in both experiments. Letters a, b, c and d of values are the rank of significant difference according to ANOVA (L.S.D. $\mathrm{p}=0.05)$.

amounts of BA, PM and BA+PM added to the soil, PM application was more efficient than BA application, however, application of $\mathrm{BA}+\mathrm{PM}$ caused the highest root colonization by $P$. indica 70 and $75 \%$ in both autoclaved and non-autoclaved soil treated, respectively.

\section{$B-F W$ control and growth of cucumber}

\section{$B-1-1$ - FW control}

It is clear from Table $7 \mathrm{a}$ and $\mathrm{b}$ that amendment of the soil with BA or PM had no or just a slight effect on Fo, both in autoclaved and non-autoclaved soil. Seed treatment with $P$. indica before cultivation in non-amended soils, autoclaved or non-autoclaved, significantly decreased the disease severity from 39.7 and $36.7 \%$ to 14.6 and $11.2 \%$, respectively. When seed treated with $P$. indica was sown into soil amended with BA, PM or the combination of both, the disease severity was even more reduced than after seed treatment with $P$. indica alone. In this respect, amendment with $\mathrm{PM}$ was more effective than with $\mathrm{BA}$, and the combinations were more effective than the single treatments.

Table 8. Effect of soil amendment with organic wastes on populations of Fo and $P$. indica in the rhizosphere of cucumber plants in autoclaved and non-autoclaved soil

\begin{tabular}{|c|c|c|c|c|c|}
\hline \multirow{3}{*}{ Amendment } & \multirow{3}{*}{$\begin{array}{c}\text { Conc. } \\
(\%)\end{array}$} & \multicolumn{4}{|c|}{ Total count $\left(\mathrm{cfu} \times 10^{4} \mathrm{per} \mathrm{g} \text { of soil rhizosphere }\right)^{*}$} \\
\hline & & \multicolumn{2}{|c|}{ Fo } & \multicolumn{2}{|c|}{ P. indica } \\
\hline & & Autoclaved & Non-autoclaved & Autoclaved & Non-autoclaved \\
\hline \multirow{2}{*}{ BA } & 2.5 & 32 & 19 & 14 & 11 \\
\hline & 5.0 & 27 & 15 & 19 & 15 \\
\hline \multirow{2}{*}{ PM } & 2.5 & 23 & 17 & 17 & 13 \\
\hline & 5.0 & 18 & 11 & 21 & 18 \\
\hline \multirow{2}{*}{$\mathrm{BA}+\mathrm{PM}$} & 2.5 & 19 & 15 & 19 & 16 \\
\hline & 5.0 & 13 & 9 & 23 & 21 \\
\hline No amendment & 0.0 & 43 & 32 & 9 & 7 \\
\hline
\end{tabular}

${ }^{*}$ Means of 6 plants per treatment each from two separate experiments. 
Table 9a. Effect of seed inoculation of cucumber with $P$. indica and soil amendment with organic wastes on fresh weight (FrW) and dry weight (DrW) per plant six weeks after sowing in autoclaved soil

\begin{tabular}{|c|c|c|c|c|c|c|c|c|c|c|c|c|c|c|}
\hline \multirow{4}{*}{ Inoculation } & \multirow{3}{*}{\multicolumn{2}{|c|}{ No amendment }} & \multicolumn{12}{|c|}{ Amendment } \\
\hline & & & \multicolumn{4}{|c|}{ BA } & \multicolumn{4}{|c|}{ PM } & \multicolumn{4}{|c|}{$\mathrm{BA}+\mathrm{PM}$} \\
\hline & & & \multicolumn{2}{|c|}{$2.5 \%$} & \multicolumn{2}{|c|}{$5 \%$} & \multicolumn{2}{|c|}{$2.5 \%$} & \multicolumn{2}{|c|}{$5 \%$} & \multicolumn{2}{|c|}{$2.5 \%$} & \multicolumn{2}{|c|}{$5 \%$} \\
\hline & FrW & DW & FrW & DrW & FrW & DrW & FrW & DrW & FrW & DrW & FrW & DrW & FrW & DrW \\
\hline Fo & $134.6^{* * a}$ & $9.6^{a}$ & $138.2^{a}$ & $11.2^{a}$ & $143.4^{a}$ & $11.5^{a}$ & $151.4^{a}$ & $11.8^{\mathrm{a}}$ & $156.2^{a}$ & $12.8^{a}$ & $158.6^{a}$ & $12.8^{a}$ & $177.4^{a}$ & $14.6^{a}$ \\
\hline P. indica & $287.2^{b}$ & $23.4^{b}$ & $374.2^{b}$ & $31.6^{b}$ & $402.2^{b}$ & $34.4^{b}$ & $415.6^{b}$ & $33.8^{\mathrm{b}}$ & $476.4^{b}$ & $38.8^{\mathrm{b}}$ & $437.4^{b}$ & $35.7^{b}$ & $489.6^{b}$ & $39.8^{b}$ \\
\hline $\mathrm{Fo}+P$. indica & $211.4^{c}$ & $18.6^{c}$ & $267.4^{c}$ & $23.6^{c}$ & $286.6^{c}$ & $25.2^{c}$ & $306.5^{c}$ & $28.2^{\mathrm{c}}$ & $354.4^{c}$ & $31.8^{c}$ & $298.2^{c}$ & $27.4^{c}$ & $387.4^{c}$ & $34.2^{c}$ \\
\hline Control $^{*}$ & $237.6^{\mathrm{d}}$ & $21.4^{\mathrm{d}}$ & $252.2^{d}$ & $22.2^{\mathrm{d}}$ & $254.2^{d}$ & $23.6^{\mathrm{d}}$ & $264.6^{d}$ & $25.4^{\mathrm{d}}$ & $282.4^{\mathrm{d}}$ & $26.8^{\mathrm{d}}$ & $271.4^{\mathrm{d}}$ & $25.2^{\mathrm{d}}$ & $305.4^{\mathrm{d}}$ & $28.2^{\mathrm{d}}$ \\
\hline
\end{tabular}

${ }^{*}$ No inoculation with Fo and $P$. indic

${ }^{* *}$ Means of 6 plants per treatment each from two separate experiments. Letters a, b, c and d of values are the rank of significant difference according to ANOVA (L.S.D. $\mathrm{p}=0.05)$.

Table 9b. Effect of seed inoculation of cucumber with $P$. indica and soil amendment with organic wastes on fresh weight (FrW) and dry weight (DrW) per plant six weeks after sowing (non-autoclaved soil)

\begin{tabular}{|c|c|c|c|c|c|c|c|c|c|c|c|c|c|c|}
\hline \multirow{4}{*}{ Inoculation } & & & \multicolumn{12}{|c|}{ Amendment } \\
\hline & \multicolumn{2}{|c|}{ No amendment } & \multicolumn{4}{|c|}{$\mathrm{BA}$} & \multicolumn{4}{|c|}{ PM } & \multicolumn{4}{|c|}{$\mathrm{BA}+\mathrm{PM}$} \\
\hline & & & \multicolumn{2}{|c|}{$2.5 \%$} & \multicolumn{2}{|c|}{$5 \%$} & \multicolumn{2}{|c|}{$2.5 \%$} & \multicolumn{2}{|c|}{$5 \%$} & \multicolumn{2}{|c|}{$2.5 \%$} & \multicolumn{2}{|c|}{$5 \%$} \\
\hline & FrW & DW & FrW & DrW & FrW & DrW & FrW & DrW & FrW & DrW & FrW & DrW & FrW & DrW \\
\hline Fo & $151.4^{* * a}$ & $12.2^{a}$ & $156.4^{a}$ & $12.2^{\mathrm{a}}$ & $163.2^{a}$ & $12.8^{\mathrm{a}}$ & $161.4^{\mathrm{a}}$ & $12.8^{\mathrm{a}}$ & $177.2^{a}$ & $14.2^{a}$ & $166.6^{a}$ & $13.6^{a}$ & $181.4^{a}$ & $15.6^{a}$ \\
\hline P. indica & $295.4^{\mathrm{b}}$ & $24.2^{\mathrm{b}}$ & $381.6^{\mathrm{b}}$ & $32.2^{\mathrm{b}}$ & $413.2^{b}$ & $35.4^{\mathrm{b}}$ & $427.6^{b}$ & $34.2^{\mathrm{b}}$ & $488.4^{b}$ & $39.3^{\mathrm{b}}$ & $445.4^{\mathrm{b}}$ & $37.2^{\mathrm{b}}$ & $501.6^{\mathrm{b}}$ & $41.4^{\mathrm{b}}$ \\
\hline $\mathrm{Fo}+P$. indica & $226.6^{c}$ & $18.6^{c}$ & $286.2^{c}$ & $23.6^{c}$ & $297.6^{c}$ & $26.2^{c}$ & $316.4^{c}$ & $29.2^{c}$ & $366.4^{c}$ & $32.6^{c}$ & $332.6^{c}$ & $28.4^{c}$ & $403.4^{c}$ & $33.6^{c}$ \\
\hline Control $^{*}$ & $243.4^{\mathrm{d}}$ & $19.4^{\mathrm{d}}$ & $269.4^{d}$ & $22.2^{\mathrm{d}}$ & $265.2^{d}$ & $24.6^{\mathrm{d}}$ & $277.6^{\mathrm{d}}$ & $26.4^{\mathrm{d}}$ & $298.4^{d}$ & $27.8^{\mathrm{d}}$ & $283.2^{\mathrm{d}}$ & $22.6^{\mathrm{d}}$ & $323.6^{\mathrm{d}}$ & $25.4^{\mathrm{d}}$ \\
\hline
\end{tabular}

${ }^{*}$ No inoculation with Fo and $P$. indica.

${ }^{* *}$ Means of 6 plants per treatment each from two separate experiments. Letters a, b, c and d of values are the rank of significant difference according to ANOVA (L.S.D. $\mathrm{p}=0.05$ ).

\section{B-1-2-Population of Fo and P. indica in plant rhizosphere}

Application of BA and PM alone or in a mixture led to a clear decrease of the Fo population in both autoclaved and non-autoclaved soil (Table 8). PM was more effective than $\mathrm{BA}$, however, a mixture of $\mathrm{BA}+\mathrm{PM}$ was even more effective. On the other hand, application of both amendments alone or in a mixture resulted in an increased $P$. indica population in the autoclaved and non-autoclaved soil. Again, PM was more effective than BA in this respect while the mixture was most effective.

\section{B-2-Growth of cucumber}

In non-amended, autoclaved (Table 9a), healthy soil (without inoculation of $\mathrm{Fo}$ ), seed treatment with $P$. indica increased the fresh weight by around $20 \%$. In amended soil the increase varied between about 48 and $62 \%$. The result obtained with non-autoclaved soil (Table 9b) was very similar, with an increase of around $21 \%$ in non-amended soil and increases between 42 and $64 \%$ in amended soil. In non-amended, autoclaved (Table 8), infected soil (= with inoculation of Fo), seed treatment with $P$. indica increased the fresh weight by 57\%, and in the presence of amendments this value almost tripled to reach $170-205 \%$. In non-autoclaved soil (Table $9 \mathrm{~b}$ ) seed treatment with $P$. indica resulted in an increase of around $50 \%$. The increase observed in amended soil varied between 83 and $120 \%$ and was thus less pronounced than in autoclaved soil.

\section{Discussion}

Despite the economic importance of sugarcane industry in Egypt, some organic wastes such bagasse, press mud (filer mud/cake) and molasses are produced daily during the manufacturing process and often accumulate causing a challenging problem regarding storage and adverse impacts of the environment. Therefore, most primitive factories in Upper Egypt commonly tend to sell press mud to contractors for use in agriculture as soil amendment or fertilizer. In most factories, bagasse is burnt for steam and power generation. The ash produced from the burning process is rich in nutrients and can be used efficiently as "bagasse ash" fertilizer in agriculture (Nakhla and El Haggar, 2014). The current work was therefore mainly focused on characterizing BA and PM as soil amendments by studying their effect on physico-chemical and biological soil properties. Another part of this study evaluated traits of the fungus $P$. indica potentially associated with disease control using the example of FW. Finally, experiments were performed in the greenhouse to study the effects of combined use of the soil amendments BA and PM and $P$. indica.

For proper decomposition in soil, it has been suggested that application of BA and PM to the soil should be one month prior to sowing (Dotaniya et al., 2016). Therefore, in the present study BA, PM and BA+PM, were added to the soil mixed well, and after irrigation with water to $75 \%$ soil moisture capacity the mixture was covered for 14 days. Afterward, the cover was removed and the mixture was left to dry for 2 weeks before starting the trials. It is clear from the results obtained that application of BA and PM alone or in a mixture improved the physical condition of the treated soil. One effect was the reduction in bulk density of the soil which ultimately increased the total porosity due to improvement of soil aeration, water retention and root development. This is similar with that was previously reported (Patil and Shingate, 1981; Kumar and Mishra, 1991; Rangaraj et al., 2007; Jamil et al., 2008; Sarwar et al., 
534

2010; Khan, 2011; Dotaniya et al., 2016). Also, application of PM at 2.5 and $5 \%$ slightly decreased the soil $\mathrm{pH}$. The reduction in soil $\mathrm{pH}$ could be due to the effect of organic acids which produced during the decomposition of organic amendments (Jamil et al., 2008; Negim et al., 2016). This was in agreement with the reports by Clarson (1983), Kumar and Mishra (1991), Khan (2011) and Dotaniya et al. (2016). It is known that PM has a high content of nutrients and $\mathrm{CaSO}_{4}$, the latter acting as a vital soil amendment in alkaline soils (Tiwari et al., 1998). Although $\mathrm{PM}$ can reduce the soil $\mathrm{pH}$, good results were obtained when it was applied in mixture with other $\mathrm{pH}$ reducing agents such as phosphorus fertilizer (Borde et al., 1984), gypsum (Reddy et al., 1973), gypsum + Zn (Chand et al., 1980) and pyrites (Singh et al., 1986). On the other hand, the increase in soil EC after addition of BA, PM and $\mathrm{BA}+\mathrm{PM}$, could be due to the high value of $\mathrm{EC}$ in organic amendments. The application of organic manures (FYM, Poultry manure and press mud) increased the electrical conductivity of the soil (Jamil et al., 2008; Ghulam et al., 2010; Khan, 2011; Negim et al., 2016). Soluble cation content was also affected (increased) by addition of BA, PM and $\mathrm{BA}+\mathrm{PM}$ in all soil treatments compared with control. This may be may be due to the chemical composition of applied organic amendments (Jamil et al., 2008; Muhammad and Khattak, 2011; Negim et al., 2016). The application of organic amendments could be raising the amount of $\mathrm{Ca}, \mathrm{Mg}, \mathrm{Na}$ and $\mathrm{K}$ in soil solution due to the dissolved $\mathrm{CO} 2$ and organic acid produced from organic amendments (Wong et al., 2009; Negim et al., 2016). Likewise, application of BA and PM to the soil up to 5\% directly increased soil contents of organic matter, macro and micronutrients such as NPK, Fe, $\mathrm{Zn}, \mathrm{Cu}$ and $\mathrm{Mn}$. However, $\mathrm{PM}$ was more effective than BA and the mixture of the two resulted in the highest increase of nutrient content. Several studies carried out under pot or field conditions recommended application of $\mathrm{BA}$ and $\mathrm{PM}$ for improving soil chemical properties by increasing the organic matter and nutrients in the soil (Bokhtiar et al., 2000; Rangaraj et al., 2007; Jamil et al., 2008; Singh et al., 2008; Sarwar et al., 2010; Khan, 2011; Dotaniya et al., 2016). Availability of nutrients including an immediate $\mathrm{P}$ release were directly enhanced by the effects of the residues of these organic wastes (Datta and Gupta, 1983) or by indirect effects during decomposition of their residues in the soil which produced a range of organic acids (Dotaniya and Meena, 2013) causing mobilization of insoluble P (Dotaniya et al., 2013). The addition of BA and PM greatly increased bacterial and fungal population in the rhizosphere of cucumber plants when added to the soil alone or in a mixture. However, PM was more effective than BA, and the mixture resulted in the highest abundance of fungi and bacteria. Ownen (1954) also reported that application of PM to the soil greatly increased bacterial and fungal populations. Increases in soil microbial diversity and populations after addition of amendments are generally attributed to an increase in easily available carbon as a food material (Singh et al., 2009). It is also known that PM encourages growth of bacteria and microorganisms (Ownen, 1954; Ochao-George et al., 2010).
In order to evaluate the effect of BA and PM on Fo and $P$. indica, these fungi were cultured in liquid media amended with aqueous extracts of BA and PM. It was observed that the water extracts of PM and the extracts from BA and PM significantly inhibited the growth of Fo. In a previous study, the aqueous extract of 10\% PM also inhibited F. solani linear growth (Pandya et al., 2009). Also, preparations from cashew (Anacardium occidentale L.) peduncle bagasse have shown an antifungal activity against F. oxysporum, F. moniliforme and F. lateritium (Santos et al., 2011). On other hand, the aqueous extracts of BA and PM significantly stimulated the growth of $P$. indica by increasing the mycelial mass production in our study. It has been earlier reported that PM is very rich in nutrients (Solaimalai et al., 2001; Gupta et al., 2011; Khan, 2011; Dotaniya et al., 2016) and encouraged the growth of various fungi including Neurospora crassa, Trichoderma viride, Aspergillus sp. and Penicillium sp. (Anonymous, 1968).

In our study we observed chlamydospores of $P$. indica within the root cortex cells of 14 and 28 day-old plants of cucumber after inoculation of seeds with $P$. indica. This is in agreement with the results of histological studies performed with the fungus on other plants colonized by $P$. indica such as wheat (Serfling et al., 2007; Yilmaz, 2013; Rabiey et al., 2015; Moharam et al., 2017), barley (Waller et al., 2007; Yilmaz, 2013), maize (Kumar et al., 2009; Rane et al., 2015) and rice (Bagheri et al., 2014). Colonization of cucumber roots with $P$. indica was also confirmed by PCR diagnosis. When PCR was performed with DNA extracted roots of inoculated plants, the PCR products were identical with the product (751-bp in length) obtained by PCR with DNA from a pure culture of $P$. indica. This was in agreement with earlier studies reporting detection of $P$. indica in colonized roots of wheat plants (Serfling et al., 2007; Moharam et al., 2017). To our knowledge, this is a first record of colonization of cucumber roots by this endophytic fungus. Moreover, in agreement with the positive effects of aqueous extracts of BA and PM on biomass of $P$. indica observed in vitro, the colonization rate of roots of cucumber with $P$. indica to was highly increased by up to 70 and $75 \%$ when the experiment was performed in soil amended with BA and PM. Taken together, this clearly showed a positive effect of PM and BA on $P$. indica.

As in other studies, a dual culture test was carried out for exploring the antagonistic activity of $P$. indica and Fo and vice versa in vitro. In this test, the inoculated plates were incubated at $28 \pm 5^{\circ} \mathrm{C}$, the most favorable temperature for growth of both fungi. In these test, a clear antagonism between both fungi was not found. A lack of an antagonistic effect of $P$. indica on other species of Fusarium such as $F$. culmorum, F. graminearum, F. verticillioides or F. oxysporum causing root diseases on different plants has been reported before (Deshmukh and Kogel, 2007; Kumar et al., 2009; Rabiey et al., 2015; Moharam et al., 2017). Also, on agar media amended with culture filtrate of $P$. indica a negative effect on mycelial growth of Fo was not seen (data not shown), confirming the results of the dual culture test.

In the present pot experiments, a significant reduction in severity of FW was observed when seeds of cucumber 
were treated with $P$. indica as compared to the disease severity of plants grown from non-treated seeds. The reduction was even more pronounced in soil amended with $\mathrm{BA}$ and PM alone with the mixture. Thus, the high reduction in disease severity observed in the pot experiment together with a clear lack of antagonistic activity of $P$. indica on Fo in vitro indicates an induction of disease resistance against FW by $P$. indica. A protection against root diseases caused by Fusarium spp. due to induction of resistance by $P$. indica has been reported before in different plants (Deshmukh and Kogel, 2007; Kumar et al., 2009; Rabiey et al., 2015; Moharam et al., 2017). Possibly, the disease reducing efficacy of the BA and PM amendments seen in the pot experiment was the result of a combined effect of the fungistatic properties of the amendments toward Fo on the one hand and an increase in the abundance of $P$. indica, especially in autoclaved soil amended with BA and PM, on the other. Another factor suspected to have contributed to the decrease in FW by the amendments was their positive effect on the microbial activity in the soil, resulting in increase populations of bacteria and fungi, particularly in the non-autoclaved soil amended with BA and PM. The increase of these microorganisms maybe has played a vital role in suppressing the pathogen in the soil. However, the role of soil biology for the mechanism of FW control after incorporation of $\mathrm{BA}$ and PM amendments along with $P$. indica in cucumber systems requires further investigation.

In this study, the biomass of vegetative growth (FrW and DrW g) of cucumber was improved after treating seeds with $P$. indica or application of BA and PM amendments to the soil alone or in mixture. However, the best vegetative growth was observed when seeds treated with $P$. indica were sown in autoclaved or non-autoclaved soil amended with BA and PM. Several previous studies have documented the role of this endophytic fungus as a growth promoter in a range of plants (Waller et al., 2005; Oelmüller et al., 2009; Zuccaro et al., 2009; Varma et al., 2012a; Varma et al., 2013; Bagheri et al., 2014; Moharam et al., 2017). Increases in plant growth and yield have been reported before (Borde et al., 1984; Singh et al., 1986; Jamil et al., 2008; Khan, 2011; Dotonyia et al., 2016).

\section{Conclusions}

From the present study it can be concluded that seed treatment with the endophytic fungus $P$. indica combined with the BA and PM soil amendments has the potential to improve soil properties. PM and BA showed positive effects on soil properties by increasing organic matter, increasing macro and micronutrients in the soil solution and by increasing the growth and resistance to FW of cucumber. Further experiments are needed to confirm that the identified treatments can manage the disease in the field.

\section{Acknowledgements}

Authors are thankful to all members of Experimental Farm and Laboratories, Faculty of Agriculture, Sohag University for financial support to carry out the research work. Also, thanks are expressed to E. Koch, Institute for Biological Control (Darmstadt, Germany) for advice and help.

\section{References}

Solaimalai A, Baskar M, Ramesh PT, Ravisankar N (2001). Utilization of press mud as soil amendment and organic manure - A review. Agricultural Reviews 22(1):25-32.

Bagheri AS, Saadatmand S, Niknam V, Nejadsatari T, Babaeizad V (2014). Effects of Piriformospora indica on biochemical parameters of Oryza sativa under salt stress. International Journal of Biosciences 4(2):24-32.

Black CA (1965). Methods of soil analysis. Part 2. ASA, 677 Segoe Rd. S, Madison, WI.

Bokhtiar SM, Islam MJ, Chowdhury SNA (2000). Effect of press mud along with inorganic fertilizers on sugarcane yield and fertility status of soil. Bangladesh Journal of Training and Development 13(1-2):175180.

Bonanomi G, Antignani V, Pane C, Scala F (2007). Suppression of soilborne fungal diseases with organic amendments. Journal of Plant Pathology 89:311-324

Borde BK, Kadam, JR, Patil ND (1984). Effect of press mud cake and phosphatic fertilizer on yield and uptake of nutrient by green gram. Journal of the Indian Society of Soil Science 32(3):512-518.

Borrego-Benjumea A, Basallote-Ureba MJ, Abbasi PA, Laarovits G, MeleroVara JM (2014). Effects of incubation temperature on the organic amendment-mediated control of Fusarium wilt of tomato. Annals of Applied Biology 164:453-463.

Chakrabarti SK, Sen B (1991). Suppression of Fusarium wilt of muskmelon by organic soil amendments. Indian Phytopathology 44(4):476-479.

Datta M, Gupta RK (1983). Utilization of press mud as amendment of acid soil in Nagaland. Journal of the Indian Society of Soil Science 31:511516.

Deshmukh SD, Kogel K-H (2007). Piriformospora indica protects barley from root rot caused by Fusarium graminearum. Journal of Plant Diseases and Protection 114(6):263-268.

Dolatabadi HK, Goltapeh EM, Mohammadi N, Rabiey M, Rohani N, Varma A (2012). Biocontrol potential of root endophytic fungi and Trichoderma species against Fusarium wilt of lentil under in vitro and greenhouse conditions. Journal of Agricultural Science and Technology 14:407-420.

Doran JW, Sarrantonio M, LiebigMA (1996). Soil health and sustainability. Advanced Agronomy 56:1-54.

Dotaniya ML, DattaSC, Biswas DR, Dotaniya CK, Meena BL, Rajendiram S, Regar KL, Lata M (2016). Use of sugarcane industrial by-products for improving sugarcane productivity and soil health. International Journal of Recycling of Organic Waste in Agriculture 5(3):185-194.

Dotaniya ML, Datta SC, Biswas DR, Dotaniya CK, Meena BP (2013). Effect of solution phosphorus concentration on the exudation of oxalate ions by wheat (Triiticum aestivum L.). Proceedings of the National Academy of Sciences, India Section B: Biological Sciences 83(3): 305309.

Dotaniya ML, Datta SC (2014). Impact of bagasse and press mud on availability and fixation capacity of phosphorus in an Inceptisol of north India. Sugar Tech 161(1):109-112.

Dotaniya ML, Meena DV (2013). Rhizosphere effect on nutrient availability in soil and its uptake by plants- a review. Proceedings of the 
536

National Academy of Sciences, India Section B: Biological Sciences $85(1): 1-12$.

Dotaniya ML (2014). Role of bagasse and press mud in phosphorus dynamics 1stedn. Lap Lambert Academi Publosher, Germany.

Fakhro A, Andrade-Linares DR, von Bargen S, Bandte M, Buttner C, Grosch R, Schwarz D, Franken P (2010). Impact of Piriformospora indica on tomato growth and on interactions with fungal and viral pathogens. Mycorrhiza 20:191-200.

Ghahfarokhi RM, Goltapeh ME (2010). Potential of the root endophytic fungus Piriformospora indica, Sebacina vermifera and Trichoderma species in biocontrol of take-all disease of wheat Gaeumannomyces graminis var. tritici in vitro, in Iran. Journal of Agricultural Technology 6:11-18.

Ghulam S, Khan MJ, Shakeebullah KU (2012). Effet of different rates of press mud on plant growth and yield of lentil in calcareous soil. Sarhad Journal of Agriculture 28(2):249-252.

Ghulam S, Khan M, Usman K, Rehman H (2010). Impact of press mud as organic amendment of physico-chemical characteristics of calcareous soil. Sarhad Journal of Agriculure 26(4):565-570.

Gilardi G, Pugliese M, Gullino ML, Garibaldi A (2016). Effect of different organic amendments on lettuce Fusarium wilt and on selected soilborne microorganisms. Plant Pathology 65:704712.

Gomez KA, Gomez AA (1984). Statistical procedures for agricultural research, 2ndEd. John Willey, New York, USA.

Gupta N, Tripathi S, Balomajumder C (2011). Characterization of press mud: a sugar industry waste. Fuel 90(1):389-394.

Ha MT, Hang Y-M, HuangJ-W (2008). Influence of organic amendment and Bacillus subtilis on mineral uptake of asparagus bean in two field soils. Plant Pathology Bulletin 17:289-296.

Harrach BD, Baltruschat H, Barna B, Fodor J, Kogel K-H (2013). The mutualistic fungus Piriformospora indica protects barley roots from a loss of antioxidant capacity caused by the necrotrophic pathogen Fusarium culmorum. Molecular Plant-Microbe Interactions 26:599-605.

Huang LD, Backhouse D (2005). Induction of defence response in root and mesocotyls of sorghum seedlings by inoculation with Fusarium thapsium and $F$. proliferatum, wounding and light. Journal of Phytopatholoy 153:522-529.

Jackson ML (1967). Soil Chemical Analysis. Prentice-Hall Inc., Englewood Cliffs, New Jersey, USA.

Jackson ML (1973). Soil Chemical Analysis. Prentice-Hall Inc. Englewood Cliffs, New Jersey, USA.

Jamil M, Qasim M, Zia MS (2008). Utilization of press mud as organic amendment to improve physic-chemical characteristics of calcareous soil under two legume crops. Journal of the Chemical Society of Pakistan $3(1): 145-150$.

Johnson JM, Alex T, Oelmüller R (2014). Piriformospora indica: The versatile and multifunctional root endophytic fungus for enhanced yield and tolerance to biotic and a biotic stress in crop plants. Journal of Tropical Agriculture 52(2):103-122.

Jun-LiHU, Xian-Gui LIn, Jun-Hua W, Wei-Shou S, Shu WU, Su-Ping P, Ting-Ting MAO (2010). Arbuscular mycorrhizal fungal inoculation enhances suppression of cucumber Fusarium wilt in greenhouse soils. Pedosphere 20(5):586-593.
Kennedy AC, Smith KL (1995). Soil microbial diversity and sustainability of agricultural soils. Plant Soil 170:75-86.

Khan JM (2011). Impact of selected doses of organic wastes on physicchemical characteristics of the soil and yield of wheat. 2nd International Conference on Environmental Engineering and applications. IPCBEE Vol. 17, IACSIT Press, Singapore pp 271-275.

Kollmorgen JF, Ballinger DJ (1987). Detection and morphology of hyphae of common bunt fungi (Tilletia laevis and T. tritici) in wheat seedlings. Transactions of the British Mycological Society 88:555-559.

Kumar M, Yadav V, Tuteja N, Johri AK (2009). Antioxidant enzyme activities in maize plants colonized with Pirformospora indica. Microbiology 155:780-790.

KumarV,Mishra B (1991). Effect of two types of press mud cake on growth of rice-maie and soil properties. Journal of the Indian Society of Soil Science 39:139-113.

Lennox LJ (1979). An automated procedure for the determination of phosphorous. Water Research 13:1329-1333.

Lindsay WL, Norvel WA (1978). Development of a DTPA soil test for zinc, iron, manganese and copper. Soil Science Society of American Journal 42(3):421-428.

Moharam MHA, Mohamed MDA, Negim EO (2016). Improvement of soil properties, growth and protection against Fusarium wilt of cucumber by Piriformospora indica and organic wastes. $68^{\text {th }}$ International Symposium on Crop Protection May 17, Ghent University, Ghent, Belgium. (Abstract) pp 9.

Moharam MHA, Mohamed MDA, Mohamed NE (2017). Piriformospora indica, a plant-root-colonizing fungus enhances growth and tolerance of wheat to seedlings damping-off caused by Fusarium oxysporum. Archives of Phytopathology and Plant Protection 50(9-10):473-490.

Moharam MHA, Negim OO (2012). Biocontrol of Fusarium-wilt disease in cucumber with improvement of growth and mineral uptake using some antagonistic formulations. Communication in Agricultural and Applied Biological Sciences 77(3):53-63.

Muhammad D, Khattak RA (2011). Wheat yield and chemical composition as influenced by integrated use of gypsum, pressmud and FYM in saline-sodic soil. Journal of the Chemical Society of Pakistan 33(1):82-89.

Nakhla A Dalia, El Haggar S (2014). A proposal to environmentally balanced sugarcane industry in Egypt. International Journal of Agricultural Policy and Research 2(9):321-328.

Negim O, Mustafa A, Fouad HA (2016). Effect of pressmud, as an organic fertilizer, on some soil properties, growth of tomato plant and infestation of Tuta absoluta under saline irrigation water. Journal of Soil Sciences and Agricultural Engineering. Mansoura University Egypt 7(8):557 563.

Njoroge SMC, Riely MB, Keinath AP (2008). Effect of incorporation of Brassica spp. residues on population densities of soilborne microorganisms and on damping-off and Fusarium wilt of watermelon. Plant Disease 92:287-294.

Ochoa-George PA, Eras JJ, Gutierrez AS, Hens L, Vandecasteele C (2010). Residue from sugarcane juice filtration (Filter Cake): Energy use at the sugar factory. Waste Biomass Valor 1:407-413.

Oelmüller R, Sherameti I, Tripathi S, Varma A (2009). Piriformospora 
indica, a cultivable root endophyte with multiple biotechnological applications. Symbiosis 49:1-17.

Ownen WL (1954). International Sugar Journal 54: 212-213. In: Solaimalai A, Baskar M, Ramesh PT, Ravisankar N (2001). Utilization of press mud as soil amendment and organic manure - A review. Agriculture Reviews 22(1):25-32.

Padmodaya B, ReddyHR (1999).Effect of organic amendments on seedling disease of tomato caused by Fusarium oxysporum f. sp. lycopersici. Journal of Mycology and Plant Pathology 29(1):38-41.

Padmodaya B (2003). Effect of soil amendments at different concentrations and incubation period of decomposition against Fusarium wilt of tomato. Journal of Mycology and Plant Pathology 33(2):317-319.

Pandya JR, Joshi DM, Sabalpara AN (2009). Evaluation of phytoextracts and organic extracts against Fusarium solani. Journal of Plant Science 4(2):180-182

Patil NN, Jadhav S, Ghorpade SS, Sharma A (2013). Isolation and enrichment of sugar press mud (SPM) adapted microorganism for production of biofertilizer using sugar press mud. International Journal ofAdvanced Biotechnology Research 14(1):96-104

Patil VD, Shingate AK (1981). Studies of the effect of different levels of press mud cake in combination with various levels of nitrogen on yield and quality of sugarcane (Co 740). Indian Sugar 31:187-188.

Prasad R, Pham HG,Kumari R, et al. (2005). Sebacinaceae: culturable Mycorrhiza-like endosymbiotic fungi and their interaction with nontransformed and transformed roots. In: Declerck S, Strullu D-G, Fortin A (Eds.). In vitro culture of mycorrhizas. Soil Biology, vol. 4. Springer-Verlag, Berlin Heidelberg pp 291-312.

Rabiey M, Ullah I, Shaw W (2015). The endophytic fungus Piriformospora indica protects wheat from Fusarium crown rot disease in simulated UK autumn condition. Plant Pathology 64:1029-1040.

Rane M, Bawskar M, Rathod D, Nagaonkar D, Rai M (2015). Influence of calcium phosphate nanoparticles, Piriformospora indica and Glomus mosseae on growth of Zea mays. Advances in Natural Sciences: Nanoscience and Nanotechnology 6(4):1-7.

Rangaraj T, Somasundaram EM, Amanullah M, Thirumurugan V, Ramesh S, Ravi R (2007). Effect of agroindustrial wastes on soil properties and yield of irrigated finger millet (Eleusine coracana L. Gaertin) in coastal soil. Research Journal of Agriculture and Biological Sciences 3(3):153 156.

Razzaq A (2001). Assessing sugarcane filter cake as crop nutrients and soil health ameliorant. Parkistan Sugar Journal 21(3):15-18.

Reddy RV (1973). Madras Agric. J. 60: 854-858. In: Solaimalai A, Baskar M, Ramesh PT, Ravisankar N (2001). Utilization of press mud as soil amendment and organic manure - A review. Agriculture Reviews 22(1):25-32.

Richards LA (1954). Diagnosis and Improvement of Saline and Alkali soil. United States Department of Agriculture, Agriculture Handbook No. $60 \mathrm{pp} 160$.

Santos RP, Marinho MM, Sá RA, Martins JL, Teixeira EH, Alves FC, ... Santos RP (2011). Compositional analysis of cashew (Anacardium occidentale $\mathrm{L}$.) peduncle bagasse ash and its in vitro antifungal activity against Fusarium species. Brazilian Journal of Biosciences 9(2):200-205.
Sarma MVRK, Kumar V, Saharan K, Srivastava R, Sharma AK, Prakash A, Sahai V, Bisaria VS (2011). Application of inorganic carrier-based formulations of fluorescent Pseduomondas and Piriformospora indica on tomato plants and evaluation of their efficacy. Journal of Applied Microbiology 111:456-466.

Sarwar MA, Ibrahim M, Tahir M, Ahmed K, Khan ZI, Valeem EE (2010). Appraisal of press mud and inorganic fertilizers on soil properties, yield and sugarcane quality. Pakistan Journal of Botany 42(2):1361-1367.

Serfling A, Wirsel SGR, Lind V, Deising HB (2007). Performance of the biocontrol fungus Piriformospora indica on wheat under greenhouse and field conditions. Phytopathology 97:523-531.

Shivanna MB, Meera MS, Hyakumachi M (1996). Role of root colonization ability of plant growth promoting fungi in suppression of take-all and common root rot of wheat. Crop Protection 15:497-503.

Singh OKDN(1986). In: Solaimalai A, Baskar M, Ramesh PT, Ravisankar $N$ (2001). Utilization of press mud as soil amendment and organic manure-A review. Agriculture Reviews 22(1):25-32.

Singh S, Dubey A, Tiwari L, Verma AK (2009). Microbial profile of stored jagger: a traditional Indian sweetener.Sugar Technology 11:213-216.

Singh Y, Singh BB, Gupta RK, Ladha JK, Bains JS, Singh J (2007). Evaluation of press mud cake as a source of nitrogen and phosphorus for rice-wheat cropping system in the indo-Gangetic plains of India. Biology and Fertility ofSoils 44(5):755-762.

Solaimalai A, Baskar M, Ramesh PT, Ravisankar N (2001). Utilization of press mud as soil amendment and organic manure - A review. Agriculture Review 22(1):25-32.

Srivastava R, Khalid A, Singh US, Sharma AK (2010). Evaluation of arbuscular mycorrhizal fungus, fluorescent Pseudomonas and Trichoderma harzianum formulation against Fuasrium oxysporum $\mathrm{f}$. sp. lycopersici for the management of tomato wilt. Biological Control 53:24 31.

Tiwari K, Bangar KS, Nema GK, Sharma RK (1998). Long-term Effect of Pressmud and Nitrogenous Fertilizers on Sugarcane and Sugar Yield on a Typic Chromustert. Journal of the Indian Society of Soil Science 46:243-245.

Varma A, Rexer K-H, Hassel A, Kost G, Sarbhoy A, Bisen P, Bütehorn B, Franken P (1998). Piriformospora indica, gen. Et sp. Nov., a new rootcolonizing fungus. Mycologia 90(5): 898-903.

Varma A, Bakshi M, Lou B, Hartmann A, Oelmueller R (2012b). Piriformospora indica: A Novel Plant Growth-Promoting Mycorrhizal Fungus. Agricultural Research 1(2):117-131.

Varma A, Kost G, Oelmuller R (2013). Piriformospora indica; Sebacinales and their biotechnological applications. In: Varma A, ed. Piriformospora indica, Soil Biology 33. Berlin, Germany: Springer-Verlag pp 17.

Varma A, Sherameti I, Tripathi S, Prasad R, Das A, Sharma M...Bagde US et al (2012a). The symbiotic fungus Piriformospora indica: review. In: Hock B, ed. Fungal Associations. The Mycota IX.2nd edn. Berlin, Germany: Springer-Verlagpp 231-254

Vieira FCS, Nahas E (2005). Comparison of microbial numbers in soils by using various culture media and temperatures. Microbiological Research 160: 197-202

Waller F, Achatz B, Kogel K-H (2007). Analysis of the plant protective 
538

potential of the root endopytic fungus Piriforomspora indica in cereals. In: Advanced techniques in soil microbiology. Veram A, Oelmüller R (Eds.). Soil Biology 11:343-354.

Waller F, Achatz B, Baltruschat H, Fodor J, Becker K, Fischer M...Kogel K$\mathrm{H}$ et al.(2005). The endophytic fungus Piriformospora indica reprograms barley to salt-stress tolerance, disease resistance, and higher yield. Proceedings of the National Academy of Sciences of the United States of America 102(38):13386-13391.

Wong VNL, Dalal RC, Greene RSB (2009). Carbon dynamics of sodic and saline soils following gypsum and organic material additions: A laboratory incubation. Applied Soil Ecology 41:29-40.

Yadav RS (2014). Biocontrol potential of Trichoderma harzianum and Pesudomonas fluorescens with organic amendments against tomato wilt caused by Fusarium oxysporum f. sp. lycopersici. International Journal of Microbial Resource Technology2(2):13-17.
Yilmaz B (2013). Optimization of Piriformospora indica application and observation of Piriformospora indica induced disease resistance against various plant pathogens in wheat and barley. MSc. Thesis, Middle East Technical University.

Yu JQ (2001). Autotoxic potential of cucurbit crops: Phenomenon chemicals, mechanisms and means to overcome. Journal of Crop Production 4:335-348.

Zuccaro A, Basiewicz M, Zurawska M, BiedenkopfD, Kogel K-H (2009). Karyotype analysis, genome organization, and stable genetic transformation of the root colonizing fungus Piriformospora indica. Fungal Genetics and Biology 46(8):540-550. 